\title{
Brussels seeks panel's help to link European research
}

Brussels. The European Commission last week launched an experiment in powersharing with the scientific community, with the inauguration in Brussels of the European Science and Technology Assembly (ESTA), a high level advisory body of 100 European scientists (see Nature 368, 385; 1994).

The main task of ESTA is to improve the quality and choice of European Union (EU) research programmes, says Antonio Ruberti, the research commissioner. The commission's other hope, he says, is that the existence of the assembly - which includes the heads of several national research agencies and six Nobel prizewinners - will help generate better coordination between national and EU research programmes.

The commission's dilemma here is that it is mandated to improve coordination by the 1991 Maastricht agreement, but only accounts for around four per cent of total spending by EU member states on research. Moreover, national research bodies (and their governments) are loathe to concede more power to Brussels.

Indeed, the creation of the assembly comes at a time when the commission badly needs allies. The 12 EU governments, represented in Brussels by the Council of Ministers, see an opportunity to claw back power from the commission, now that its bruising president, Jacques Delors, has been replaced by the less confrontational Jacques Santer, formerly prime minister of Luxembourg.

EU governments also hope to strip yet more powers from the commission at a review conference of the Maastricht Treaty scheduled for 1996, in line with a general view that political control in Europe should remain as decentralized as possible.

Research is a relatively small part of the commission's work, but one of its most controversial. Some argue, for example, that the EU should switch funding away from 'pre-competitive' research to focused social and commercial goals, as part of a 'shock therapy' industrial policy.

What direction EU research takes will depend heavily on the outcome of ongoing negotiations on the form of the incoming commission. Some advocates of industrial policy favour merging the directorate for industry (DGIII) with the research activities of research and education (DGXII), particularly as the use of research funds as explicit subsidies to industry has been made easier by the recent GATT agreement.

But another prospect would be the splitting of research and education into independent directorates; if Sweden, Finland, Norway and Austria join the EU as expected, the commission will need to slice its salami more thinly to provide jobs for their commissioners.

Much will also depend on who replaces Ruberti as research commissioner at the end of the year. Even if a merger between DGIII and DGXII were excluded, for example, the possible appointment of a commissioner from a country such as France, which is keen on industrial policy, could amount to much the same.

Whatever direction the commission takes, it hopes that allowing the assembly to comment on all proposed EU programmes will

\section{IMAGE UNAVAILABLE FOR COPYRIGHT REASONS}

\section{Ruberti: aiming for better coordination}

strengthen its hand in subsequent negotiations with the Council of Ministers, as such proposals will now appear to carry the endorsement of the research community.

Some government officials in member states say, however, that they will not be moved by the "rubber stamp" of a body seen as the commission's "poodle". Whatever happens, the council will increasingly dominate the commission, says one official at the French science ministry. When EU governments meet in 1996, for example, they will probably try to reduce the powers of the commission's main ally, the European Parliament, by trying to abolish its current veto on the research budget.

Another tactic of the commission may be to use the assembly to increase its influence over national funding agencies and European-level bodies, such as the European Space Agency as it will be more difficult for them to criticize decisions they have been involved in.

National agencies are seen by some in Brussels as a potential threat to the commission's role in overseeing and shaping European research, giving as examples pressures to devolve management of research away from Brussels and the recent decision of several national agencies to create their own transnational 'associated European laboratories' without the help of the commission.

Such a tactic could backfire, however, says one commission official, who talks of a 'Frankenstein scenario' where the commission, having created an assembly of powerful individuals close to itself, might subsequently find its power base being eroded from within.

\section{Ireland agrees to cover tax costs on Wellcome grants}

Munich. The Wellcome Trust, Britain's largest medical research charity, has withdrawn a threat to discontinue its support for research in Ireland after reaching agreement with the Irish government in a dispute over the payment of value added tax (VAT) on research equipment.

After prolonged negotiations, the Irish government has now agreed, through its Health Research Board, that it will in future cover the costs of VAT on Wellcome grants in a venture it describes as "co-funding".

The trust had challenged its obligation to pay VAT at a rate of 21 per cent on all such equipment bought for Irish grant recipients. It had argued that all of its money should go to research without being taxed in this way.

The problem had surfaced as the result of three major programme grants awarded by the Wellcome Trust to Irish scientists since 1990. Previously, grants from the trust amounted to only around $\mathrm{I} £ 100,000$ (US\$153,300) a year; but as a result of the new awards Wellcome's funding of research in Ireland has risen to I£5.4 million over the past four years, and it has faced a I $£ 400,000$ bill for VAT.

In response, the government had argued that it had little room to manoeuvre within taxation rules introduced by the then European Economic Community in 1989, forbidding members from creating new exemptions to VAT liability. (In the United Kingdom, such equipment was already exempt before the new rules were introduced.)

Earlier this year, after the trust had threatened to withdraw all funding if the tax demand was sustained, the government announced that items of equipment for medical research bought by charities at a cost of more than I£20,000 would be liable for a VAT refund.

But this did not satisfy the trust, as few single items of equipment cost more than I£20,000. For example, Brian Harvey, professor of physiology at the University of Cork, says that he spent I $£ 290,000$ on equipment this year out of a grant from the trust but that the most expensive single item only cost $I £ 19,000$.

- Seamus Brennan, Irish minister for Commerce and Technology, is due to make an interim statement on 19 September about the work of the Science, Technology and Innovation Council, a body of 18 scientists, industrialists and civil servants, which was set up in February to review Irish science policy. Brennan's statement is expected to include a promise of more funding for research; the government was heavily criticized last year for failing to provide any new money for non-medical basic research.

Alison Abbott 